local schools. The junior section also largely contributed to the success of an excellent nature-study exhibition by displaying specimens, examples of their field-work, notebooks and drawings.

The presidential address to the Zoological Section was given by Sir Philip Manson-Bahr, who spoke on "The Contribution of Zoology to Medicine". He dealt with the early investigations into the causes of elephantiasis and malaria and with subsequent work upon the life-cycles of the insects responsible for these and other diseases. A. J. Low gave the presidential address to the Geological Section and conducted an excursion to the Jealott's Hill Research Station of Imperial Chemical Industries, Ltd., where he demonstrated some of the points of his address dealing with soil fertility, the influence of leys, microlysimeters and soil profiles,

Mr. Seth-Smith's presidential address to the Union was on "Man's Control of Wild Animals". He commenced by saying that there are people who think that zoological gardens should not be allowed to exist, as it is cruel to confine any wild animal. Such people invariably say they do not visit the zoo because they do not approve of it. Mr. Seth-Smith said that he has always been fond of animals and so of zoos, for there one can see animals which one could never hope to see in a wild state, can study their forms and actions, and know them individually and intimately. All domesticated animals were derived from wild species, and the world is now dependent upon them for its very existence. The camel was domesticated so long ago that it is not known where its wild home was. Job possessed six thousand of them, so that they were domesticated before his time. In England the first real zoological gardens was established by Henry $\mathrm{I}$ at Woodstock in Oxfordshire ; it was removed to the Tower of London by Henry III and was transferred to Regent's Park, London, on the formation of the Zoological Society in 1829 . Zoos are of the greatest educational value, for though the student can read about animals and see their stuffed skins in museums, it is not until he observes them in the wild or in captivity that he acquires a true idea of their living form.

Dealing with the problem of how do animals feel about being in a zoo, Mr. Seth-Smith said his thirty years of experience as curator led him to think that the majority, if capable of choosing, would vote for a safe and comfortable home in captivity. Most animals in a zoo are born there or are brought in from the wilds when quite small babies. Most wild animals have their own areas in which they live, and in captivity they regard their enclosures as their territories and apparently are not particular as to their size. Scientific experts are employed to ensure the health and happiness of the animals. As an example, almost every wild animal suffers from internal parasites. The very first thing at a zoo with a new arrival is thorough examination for, and treatment of, these pests. Very few wild animals die of old age or sickness. The majority are preyed upon, while the predators when old or infirm either die of starvation or are themselves killed. In zoos they live their full lives, the span of which is longer than their chances in a native haunt. Man is the greatest enemy of all wild life; his greed, cruelty and ignorance are leading to its extermination even to-day. Wild animals are afraid of man when taken under his control; but when well treated, well fed and safe from enemies, they soon become reconciled and regard man as their protector. Some animals have been saved from total extinction by being taken into zoos and collections. Were it not for zoological gärdens we should have a poor idea of the wonderful animals that share the earth with us and should have to rely chiefly upon the stories of hunters, whose chief idea was perhaps to magnify the danger in their destruction.

Other events that took place at the meeting are, briefly, as follows. Prof. F. W. Jane, as president of the Botanical Section, spoke on "Trees and Scenery", and $\mathrm{H}$. H. Coghlan chose for his presidential address to the Archæological Section the theme "Aspects of Prehistoric Metallurgy in Southern England". Excursions were conducted to Frensham Pond and Haslemere Museum with Major Maxwell Knight and Francis Rose as leaders. C. D. Ovey described aspects of weather and weather forecasting, showing 'Kodachrome' slides of features of meteorological interest. $\mathrm{He}$ stressed the importance of relating scientific observations with those of the field naturalist and the farmer. At the general assembly the methods of developing the usefulness of the Union to its affiliated societies was discussed at length and a sub-committee appointed to formulate schemes for that purpose.

\section{SOUTH-WESTERN NATURALISTS' UNION}

\section{ANNUAL CONFERENCE}

$T$

'HE South-Western Naturalists' Union held its 1951 annual Whitsuntide conference (the twentyfourth) during May 11-14 at Taunton as guests of the Somerset Archæological and Natural History Society. It was to this Society, and particularly to the hard work of the local secretary, A. D. Hallam, in planning the programme, that the success of the conference was largely due.

A reception was held by the Mayor, Councillor W. F. Heywood, at the Municipal Buildings on the evening of May 11, and then on the following day nearly sixty members visited the Blackdown Hills under the leadership of Mr. and Mrs. Hallam. Halts were made at Priors Park Wood, Britty Common, Castle Neroche and Ashill Church. At Priors Park Wood, where many birds, including the nightingale, were heard and where several badger setts were seen, the attention of the botanists was directed to the marked influence that changes in the geological formation had upon the vegetation. On Britty Common exposures of the Upper Greensand and overlying gravels were examined by the party. H. St. George Gray conducted the party over the earthworks of Norman date known as Castle Neroche, and the interesting features of Ashill Church were explained by Mr. Hallam. In the evening, W. A. Seaby lectured on Ham Hill, where many important finds of late Iron Age and Roman date have been made; the talk was amply illustrated by lantern slides.

Most of May 13 was taken up by an excursion to the region around Minehead. In the morning, Porlock Marsh was explored, under the guidance of $H$. G. Hadden, for plants and animal life; and members visited the village of Bossington, after which they drove to Horner Woods and from there to Minehead. After tea the party divided; one half visited Cleeve 
Abbey, which was described by Mr. Seaby, and the other half, the cliffs at Watchet, where the Keuper and Lower Lias are well exposed. The geology was explained by Mr. Hallam and Dr. Stanley Smith. In the evening Peter Scott, president of the Union, delivered his address; he explained two coloured films, one of bird life in northern Europe taken during his visit to Scandinavia in 1950, and the other illustrating experiments in netting wild geese for the purpose of ringing. In this work, nets are carried over the flock after it has settled, by means of rockets electrically exploded.

The final morning was occupied by the council and general meetings, with A. O. Rowden presiding over both. In the course of his remarks at the general meeting, Mr. Rowden alluded to the recent public inquiry into the use by the military of Braunton Burrows and to the matter of footpaths. The secretary reported that the South Western Naturalists' Union embraces at the present time twenty-one affiliated societies or sections of societies.

\section{SILTING IN BRITISH RESERVOIRS}

\section{BY R. M. PROTHERO}

$\mathrm{A}^{\mathrm{n}}$ RTICLES in previous issues of ature $^{1}$ have stressed the need for the proper study of the relationship between rainfall and run-off in Britain, since its influence in promoting soil erosion, dependent on the vegetation cover and on the soil cover itself, may be more considerable than we imagine. There is the danger that because of the lack of spectacular examples of soil erosion such as occur in other parts of the world, we may ignore it and fail to realize its presence. As a result of this attitude, precise information is practically non-existent and it is necessary to rely on evidence which is fragmentary in nature and which has often been collected only incidentally.

Important evidence relating to the removal of soil by heavy rainfall is provided by information on the silting, caused by the deposition of this material, of British reservoirs. A survey, covering twenty-eight of the major water-undertakings in Britain, revealed in the first place an absence of any co-ordinated information. An attempt to survey the floor of a reservoir in the Tâf Fawr valley, Breconshire, during the drought of 1949 was unfortunately unsuccessful owing to the onset of rain. This would undoubtedly have provided important and precise evidence as to the rate of silting in that area.

It is possible to prevent the transport of material of large size into reservoirs by the construction of catch-pits and wreck-lodges in the tributary streams. To prevent the entry of finer material, carried in suspension during periods of high stream flow, is a more difficult problem. Such material, deposited on the floor of a reservoir, may accumulate in a short time and seriously reduce its capacity. In Great Britain examples are not so outstanding as in the United States, where in 1934 the Soil Conservation Service reported that in a survey of fifty-six reservoirs, it was found that thirteen major dams, with an average height of $30 \mathrm{ft}$., had silted up completely during an average life of twenty-nine years.

The most outstanding example in Britain known to me, of nearly a 50 per cent reduction in capacity in seventy-eight years, has already been quoted in a previous article ${ }^{2}$. Rates of silting vary considerably : from an accumulation during a hundred years of $6 \mathrm{ft}$. of silt on the floor of a reservoir with an area of 40 acres and an average depth of $25 \mathrm{ft}$. at the time of construction; to 6 in. accumulated over a 44-year period. In many of the reservoirs there is no marked silting at all, but in eleven out of the twenty-eight undertakings for which information was received it will become serious within the next hundred years. But even if the rate of silting is slow, we must take a long-term view of our facilities for providing water, remembering that demands on available supplies are steadily increasing. In four reservoirs built in $1798,1830,1876$ and 1880 , capacity has been reduced by $12,12,5.5$ and 8 per cent respectively; but the situation will become serious only if an increased demand exceeds the surplus available at the present time. In such circumstances the engineer reported that it would be more practical to increase capacity by raising the top-water-level of the reservoirs rather than to attempt to remove the silt. In only one instance was there an actual reference to allowance being made for reduction in capacity by silting at the time of the construction of the undertaking. The allowance was for a 20-million gallon reduction in the case of one reservoir and of 10 million gallons each for the other two. But though allowance had been made for reduction in total capacity, several hundred tons of silt had to be removed from around the draw-off tunnel of one of the reservoirs in 1933 .

The problem of silting does not appear to have been allowed for in the calculated capacities of the reservoirs now being constructed as an integral part of the hydro-electric power schemes in the Scottish Highlands. In fact, the possibility of the problem arising does not seem to have been considered. A recent article on the developments taking place ${ }^{3}$ stated that, in addition to the influence they would exert on flood control, "The reservoirs will also act as traps for sand and silt which at the present time are washed down to the sea and in many places, particularly on the north-east coast, have filled up estuaries and harbours".

While acknowledging the benefit to Scottish harbours, it must be pointed out that this will only be attained at the expense of creating a problem in the reservoirs themselves. The dredging of a harbour would appear to be a much simpler operation than the removal of silt from a reservoir, quite apart from the interference with water supply to the turbines entailed in carrying it out.

Silting is most marked where erosion, particularly by gullying in the beds of the streams feeding the reservoirs, takes place in deposits of sand and peat. It is also a feature where glacial till, widespread in the north and west of Britain, is being eroded. In being complementary to erosion, silting is the most significant evidence available of the existence of the former. Even if silting may not become a serious problem for a hundred years or more, the time to take action to prevent it is at the present. The remedial measures necessary have been stated in previous articles; but in order that they may be planned to produce the maximum effect it is essential that a considerable body of accurate information be accumulated on the related factors of rainfall, run-off, erosion and silting.

${ }^{1}$ Nature, 164, 805 (1949); 168, 584 (1950).

2 Nature, 168, 584 (1950).

s Scot. Geog. Mag., 66, No. 2, 74 (1950). 